\title{
Bank employees' engagement in corporate social responsibility initiatives at a South African retail bank
}

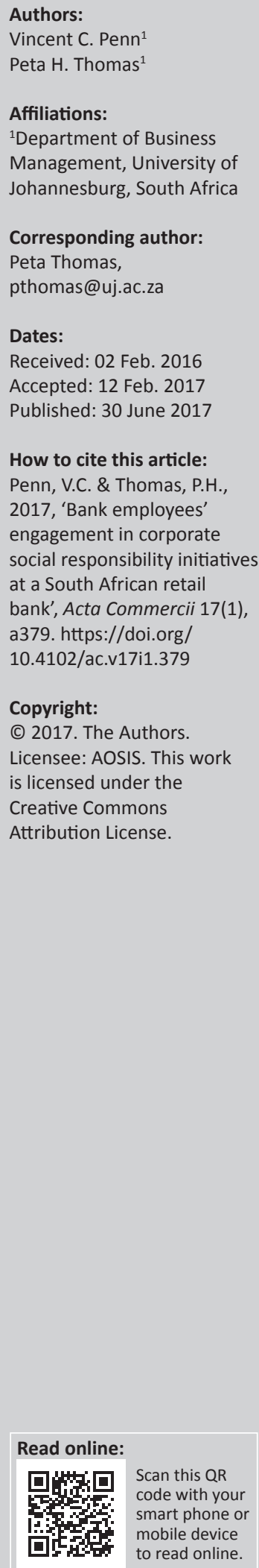

Orientation: Many firms encourage employees to undertake corporate social responsibility (CSR) projects. With any project, it is important that firm resources are committed to create valued outcomes for stakeholders.

Research purpose: The study purpose was to gain insight into criteria that can practically help define the success of employee run CSR projects.

Motivation for the study: CSR activities are reported in literature as creating valuable intangible and tangible assets for firms when planned as strategies to improve brand reputation, customer loyalty and future profit. This research reviews a South African retail bank that promotes CSR undertakings to employees exploring the bank's support for employees engaged in CSR.

Research design, approach and method: Two of the bank's completed community CSR projects were identified by the bank's senior CSR managers for this review. Qualitative interviews were undertaken with employees, bank CSR managers and project recipients. Participant interviews were transcribed into text then analysed to identify where stakeholder value diminished on these projects.

Main findings: The study found that this bank's CSR processes do not fully support the employees, detrimentally affecting the ability of the employees to optimise project outcomes.

Practical or managerial implication: Because employee CSR efforts are often aligned with a firm's value creation strategies, optimising the project management of employee CSR activities can improve the value of the outcomes achieved.

Contribution or value add: Determining specific conditions that influence successful project management of employee CSR projects can help to improve the potential of CSR projects in co-creating optimised value for stakeholders.

\section{Introduction}

Historically, firms were engaged in corporate social responsibility (CSR)-related activities as philanthropy, giving money, goods and services as a benevolent act, not linking such actions strategically to marketable and profitable benefit for the firm (Madden, Scaife \& Crissman 2006:50). More recently, many companies worldwide voluntarily abide by CSR thinking as espoused by the United Nations Global Compact on the value of bettering society through CSRrelated business practice (Global Corporate Sustainability Report 2013:4). This research looks at a South African retail bank's CSR projects implemented by employee volunteers (EVs). The bank sees their efforts as a strategically project-managed contribution to bank value. The bank is one of South Africa's largest financial service providers and falls among the top five retail banks in South Africa. This bank interacts with its customers through a combination of physical and electronic channels, offering a comprehensive range of banking services from basic products and services to customised solutions for commercial and corporate markets. South African retail banks offer similar services to those of competing retail banks. So, strategic actions that increase intangible assets such as brand awareness, brand image, reputation, overall legitimacy and trust among present and potential customers (including the employees as internal customers) can be argued as being sought-after differentiators against comparable competitors. Research indicates that stakeholders more readily support firms who do undertake CSR initiatives that address challenging issues of society (Barkay 2012). CSR research suggests that firms now deliberately develop mutually beneficial relationships of trust as a planned strategic outcome of community CSR activities (Bhattacharya, Korschun \& Sen 2009:257; Bronn \& Vidaver-Cohen 2009:91; KPMG 2015; Maignan \& Ferrell 2004:12; Oyetayo, Oluwaseun \& Dunsin 2014:212; Pearce \& Robinson 2011:52; Smith \& Cronje 2003:452; UNIDO 2002:67; White 2012:4). A KPMG 2015 survey of 532 
senior executives in 41 countries indicates that ' 61 percent of senior executives in the consumer markets industry have building consumer trust as a core value'. KPMG reports that many of these managers commonly use CSR actions to gain consumer trust to encourage consumer loyalty (KPMG 2015). Proponents of CSR note that firms should be viewing themselves as both participants and beneficiaries - together with their staff, other stakeholders and host community accordingly generating financial and brand shareholder value while leaving a positive footprint on society (Bhattacharya et al. 2009:257; Boznik \& Mulej 2010:29; Louw \& Venter 2008:323; Mostardeiro 2007:61; Ofori, Nyuur \& S-Darko 2014:8; Pérez \& del Bosque 2014:224; Smith \& Cronje 2003:452). That said, several authors conclude that their research suggests not all firms adopt CSR as 'business strategy', still placing it as a side line to main business purpose or only responding when external pressures (for instance, legislation or a popular business trend) drive them in a CSR direction (Campbell 2007:963; McPhee \& Wheeler 2006:44; Mostardeiro 2007:65; Raman, Lim \& Nair 2012:88). CSR is known to require an ongoing communication discourse between firms and their internal and external project stakeholders to be successful (Brusseau, Chiagouris \& Brusseau 2013; Pandi-Perumal et al. 2015:2). Pandi-Perumal et al. (2015:8-11) highlight critical project points where communication can reduce risk - stakeholder engagement (defining project inputs), project execution (mapping project implementation) and value creation (describing desired outputs). Beasley and Frigo advocate that stakeholder inclusion for communication flow is essential to project success. They and other authors state that firms have a responsibility to eliminate risks from arising in every business process, including CSR activity (Beasley \& Frigo 2010:36; Hinson \& Ndhlovu 2011:333; Van Os et al. 2015:878). This research sought to shed light on the extent to which the process of the bank's employee CSR activity is regarded as a bank business value-generating process minimising risk and maximising benefits. This research answers the associated questions: How do employees and the community engage for CSR initiatives? And, can this engagement be improved? This research used the assumption from the discourse on the South African CSR environment of Hinson and Ndhlovu (2011:73) - that Corporate Social Investment (CSI) is an integral element of CSR. These authors argue that an indivisible CSI/CSR South African phenomenon has emerged, originating during the apartheid era as a local business philanthropic survival strategy for foreign firms wanting to operate within apartheid South Africa, and has continued as CSR (Hinson \& Ndhlovu 2011:82).

\section{Literature review}

Poolthong and Mandhachitara (2009:410), in research on Thai banks' manner of valuing their CSR activities, note that the size of tangible resources allocated to a CSR community project has been traditionally used as the only indicator of its worth to a beneficiary community. Although this measurement of CSR performance is tangible from financial shareholders' perspectives, Poolthong and Mandhachitara
(2009:421) suggest projects need also be assessed from the intangible society value perspective. They point out that gathering participant and community views about the chosen project and its outcome value would be a more realistic barometer in terms of fulfilling community need. The authors argue that the value of this second action, although difficult to measure and interpret in tangible terms, has shown a 'direct and positive association between CSR activities and attitudinal loyalty' (Mandhachitara \& Poolthong 2011:129). Raman et al. support this, noting that in their research, CSR is moving to being an essential element in competitive advantage creation - no longer being a 'nice to have'. The authors note that CSR should be managed as a business strategy. CSR strategy ensures the employees and community create a vision of what constitutes 'shared value' with longterm positive intangible and financial implications (Evans \& Davis 2014:143; Hamann et al. 2006:51; Raman et al. 2012:88). This increased momentum for recognising the value of CSR as a business advantage can again be noticed in a relatively recent, highly escalated focus from firms including banking in the concept of responsible investment (RI). The RI approach (suggested in the South African context by the Johannesburg Stock Exchange as the Socially Responsible Investment Index) seeks to be explicit in setting down what the social (intangible) returns plus financial returns are to be attained from CSR projects (Hinson \& Ndhlovu 2011:342; Jane 2008). The RI principle integrates environmental and social needs within good corporate environmental, social and governance (ESG) principles. Institutional investors interested in the duality of returns being both financial and ESG can exert pressure as do institutional legal regulators (Campbell 2007:963; Waddock 2010:11). Yet, SRI in South Africa has to date been largely ignored by mainstream investment banks and pension funds (Richardson \& Cragg 2010:22). Patel and Mushonga (2014:57) suggest a cause indicated in their research that South African companies currently struggle to make CSR value derived from intangibles (loyalty, brand recognition and others) palatable in terms of shareholder economic performance. A community-centred CSR approach is necessary, but intangible value from a CSR project is often not visible in the short term (Bester \& Cronjé 2014:216). Gaining the first definition of what value looks like to a community or shareholders has to be established prior to the project commencement. CSR projects intent on delivering diverse stakeholder value should include the step of evaluation of needs in defining the balance between community needs and the ability to deliver or value to the donor of delivering the project (Crain \& Abrahams 2008:31-32; Du Preez \& Van Zyl 2015:6; Pearce \& Robinson 2011:145). In an effort to establish CSR project management guidelines for all stakeholders that support risk mitigation, Varajão et al. (2014) have chosen to gather best-practice criteria from 80 successful project delivery firms in two diversely different industry disciplines. The criteria identified are used as guiding anchor themes to concluding successful project management in this research. The senior management of 40 Portuguese software development and 40 construction companies place 'well defined objectives' and commitment to '[user/recipient] requirements' plus comprehensive 'project planning' as top 
'pre-implementation engagement' criteria in ensuring project success (Varajão et al. 2014:586). The participants have noted that attaining co-created objectives necessitate constant stakeholder communication to minimise 'value creation' gaps between actual outputs and expected outputs. Project value creation depends on ensuring quality during 'project execution', with participants noting the need for 'frequent control check points' that engage experts and stakeholders together looking for ways 'for resolving conflicts' (Varajão et al. 2014:588). Pre-implementation engagement, project execution and value creation were used as themes in the design of the research questions of this research. Taleb, Goldstein and Spitznagel (2009:29) point out that risk management processes often mean management only using 'hindsight as foresight' and not scenario planning for possible risk before it happens, or reviewing and learning from past experiences.

Employee voluntary CSR activity is promulgated through an awareness programme for volunteers, which is much encouraged by the researched bank. An obvious risk immediately emerges. Employees may not be specialists in project management or even the field of knowledge required for a specific project despite their enthusiasm and great ideas. De Paço and Nave (2013:556) note that many firms underestimate the risk of ignoring EV project management preparatory training with a common result being employee dissatisfaction with their volunteering experience and their firm. There is consequently the risk of employees making negative comments about the firm to community members and other stakeholders (Theofilou \& Watson 2014:374). Bergeron (2007:1086) agrees with the need for project management training. This author adds that research suggests yet another risk for EVs if the project outcome is not as expected from the perspective of the firm; this sometimes curtails the employee career advancement. It is understandable then, when considering the EV effort in terms of time and creativity on a CSR project, that employees may find the risk of project participation too great, rather putting effort into job-related work that reaps career rewards (Bergeron 2007:1090). De Gilder, Schuyt and Breedijk (2005a:2, 2005b:145) and, more recently, McCallum, Schmid and Price (2013:483) make claim, however, that participants in EV initiatives often display more positive work behaviour than those not involved, resulting in improved individual work performances for the benefit of the organisation. CSR involvement is also considered as enabling for employees to see corporate volunteering programmes as more than just the firm practising philanthropy (De Gilder et al. 2005b:145). Ferreira and De Oliveira (2014:375) assert that businesses with successful CSR programmes tend to recruit better qualified applicants because the applicants have chosen the job because they like the CSR attitudes of the business. These researchers note that involvement in CSR helps in building useful business skills, enhancing employee morale and promoting retention of existing employees in the firm (Ferreira \& de Oliveira 2014:371). Table 1 summarises further recent research that reflects project characteristics discussed here in CSR EV-actioned projects.

\section{Research bank corporate social responsibility activities}

The following particulars of the bank's CSR activities have been obtained with permission by one of the researchers (a bank employee). The bank has a national footprint with consumer access in many formal residential settlements throughout South Africa. This bank has an integrated reporting policy on CSR, which highlights an overall citizenship agenda as a primary objective of every CSR activity, and, in doing so, recognises that CSR enhances the firm's relevance to communities whose loyalty in the long term defines the bank's viability. This seeks to position the bank as a corporate citizen within participatory systems of bank and society seeing beyond only financial returns. The bank's CSR compliance encompasses and acknowledges what is covered by both South African legal requirements (Institute of Directors Southern Africa 2009) and the UN global compact sustainability agendas through a wide umbrella of CSR activities. The bank has attempted to manage CSR risk by defining standard methodologies for internal and external stakeholder engagement, heightening

TABLE 1: Recent studies undertaken of project characteristics typical in corporate social responsibility initiatives.

\begin{tabular}{|c|c|}
\hline Authors & Description \\
\hline Barkay (2012) & $\begin{array}{l}\text { - Inclusion of EVs in firm CSR planning and projects is crucial in establishing a link between the firm and the project through the EVs. } \\
\text { - A business-case model for employee involvement in communities is that it 'improves the relationship between management and employees, } \\
\text { creates solidarity, and enhances employee morale' (Barkay 2012:58). }\end{array}$ \\
\hline Brusseau et al. (2013) & $\begin{array}{l}\text { - The firm's core CSR culture often does not really mesh with the stated purpose of their CSR, meaning stakeholders get mixed messages such as: } \\
\text { is the CSR lip service or does it really serve the community or only the firm? The firm's CSR values should be meaningful to all stakeholders. }\end{array}$ \\
\hline McCallum et al. (2013) & $\begin{array}{l}\text { Indicators for successful EV projects: } \\
\text { - EVs should learn on the project, } \\
\text { - EVs should learn from working as a team, } \\
\text { - firm should always maintain a strategic overview with the EVs and assure a sound project support systems are in place, } \\
\text { - evaluate the project progress at many points, make adjustments goving forward, } \\
\text { - CSR project cost and time spent on risk reduction can be realised but be aware that they take time to be seen, } \\
\text { - employee retention, knowledge and skills generally improve from participation in a successful EV project. }\end{array}$ \\
\hline Van Os et al. (2015) & $\begin{array}{l}\text { - People do not want to be associated with things they consider negative, but a failed or inadequate CSR project can send this message to } \\
\text { internal and external stakeholders about the firm's identity. } \\
\text { - Risk analysis on a project relies on the quality of involved stakeholder cooperation; withholding support or information exasperates risk. }\end{array}$ \\
\hline Pandi-Perumal et al. (2015) & $\begin{array}{l}\text { Working collaboratively supports the success of a project } \\
\text { - Serve all stakeholder interests in a bi- or multi-directional, continuous communication manner. } \\
\text { - Analyse all interactions and the progress of the project with its stakeholders ongoingly. } \\
\text { interests. }\end{array}$ \\
\hline
\end{tabular}

EV, employee volunteers; CSR, corporate social responsibility. 
awareness of their business's ethical culture and of a need to continually improve project service levels to clients and communities. CSR values are upheld by a dedicated team of CSR managers. The bank currently has two options for CSR project implementation. Option 1 ensures the quality of a project by ensuring an appropriately competent external business partner with specialised project knowledge to facilitate maximum value creation. This is often carried out by forming partnerships with the South African government or reputable not-for-profit (NPO) organisations. The bank also considers this a risk management strategy, as access to specialist staff and resources through these partnerships brings with it a degree of risk reduction, as both external partner types generally have their own well-developed project management and risk management processes to add to those of the bank's project management structures. The bank actively manages CSR value creation in option 1 . Option 2 is projects driven solely by bank employees. This second option receives no CSR project management or risk guidelines, or checks of employee capabilities. The only criterion set by the bank is strict adherence to a process to access project funding from the CSR managers to ensure that public and private shareholder funding is released for genuine community CSR activities.

\section{Research design}

The research focused on two EV CSR projects, both targeting local high schools. The two projects were chosen for the study by the bank's senior CSR managers who wanted to learn why Project 1 worked better than Project 2. As the sampling across CSR projects was limited to this bank, the findings might not be applicable to all employee CSR projects, but did provide insight into how EV projects were delivered.

\section{Research method}

A qualitative research methodology was applied and primary data gathered from specific participants involved (Table 2). A qualitative approach allowed for discussion of the projects with individual participants, useful in establishing project priorities and learning about practical implementation (Tustin et al. 2005:182). The two CSR community projects took a similar implementation time (one year).

In both projects, the employees themselves identified the communities with whom they wanted to work. Project 1, which went to local High school 1, conducted a needs analysis with the principal and vice-principal, and the researchers realised that the school was lacking some basic requirements needed for a comfortable learning environment. Project 1 delivered to this needs analysis as follows: renovation of toilets; lights fitted in classrooms; establishment of a school vegetable garden; teaching interventions of mathematics, accounting, introductory computer training and science for Grades 11 and 12 for the period of the project. Outcomes set by Project 2 were without prior consultation with the school, undertaking to teach children at High school 2 how to save money and to turn a dilapidated classroom into a library. The role of bank CSR managers was to ensure collection of evidence that supported that both schools were registered as public secondary educational institutions with the Department of Higher Education of South Africa before releasing bank funds.

\section{Data collection}

Responses from one-on-one, open-ended, semi-structured interviews were gathered from specifically selected participants, all highly involved in each project. The participants were three senior CSR managers, three key project employee team members from each of two projects, the school principal, the vice-principal and a teacher for Project 1 as well as the school principal, the vice-principal and a teacher for Project 2. These face-to-face, in-depth interviews averaged $50 \mathrm{~min}$ each. Each interview was recorded with a voice recorder, then transcribed verbatim and reviewed by the researcher. Bank employees and managers were interviewed in their bank offices, whereas the school participants were interviewed at their schools.

\section{Data analysis}

This primary data analysis was based on the use of qualitative thematic content analysis to interrogate interview transcripts where categorisation of participant findings was derived in relation to the three project management themes - preimplementation engagement, project execution and value creation (Elo et al. 2014:2). Data transcription and analysis began as soon as the first interview had taken place helping in directing the next interviewer-interviewee conversation richness by constantly improving interview interactions (Corbin \& Strauss 1990:6). Because a substantial body of knowledge exists on project management and on the purpose of CSR, plus the fact that the employees' CSR volunteering experiences have been influenced by the bank's financial risk management policy but no other bank CSR policies, inductive reasoning is argued as appropriate (Elo \& Kyngäs 2008:109). Open-coding of primary data first identified variables related to EV CSR project management. Then, open codes were grouped by affinity under each of the three theme descriptors (Corbin \& Strauss 1990:12-13), using the background of how to create project value formed by the literature review

TABLE 2: Project team description

\begin{tabular}{llll}
\hline Team attributes & Total in team & Gender & Previous project experience \\
\hline Project 1 very successful & $\begin{array}{l}\text { Used no family members to } \\
\text { complete the project }\end{array}$ & $\begin{array}{l}8 \text { Male } \\
\text { 2 Female }\end{array}$ & $\begin{array}{l}\text { All had participated in community projects and } \\
\text { additionally currently manage small internal business } \\
\text { projects within the bank. }\end{array}$ \\
$\begin{array}{ll}6 & \text { The 10 members hold management } \\
\text { Project 2 moderately successful }\end{array}$ & $\begin{array}{l}\text { Used 3 family members to } \\
\text { help complete the project }\end{array}$ & $\begin{array}{l}\text { All had participated in a single previous community } \\
\text { project as a team but do not carry out management } \\
\text { projects within the bank. }\end{array}$ \\
\hline
\end{tabular}


(Flick 2009:178). The degree to which each team's CSR intervention was successful was ascertained through comparison of the three stages in each project - stakeholder engagement, project execution and value creation.

\section{Reliability and validity}

Reliability refers to the extent to which the techniques applied in data collection or the analysis thereof will yield consistent results (Babbie \& Mouton 2004:119; Saunders, Lewis \& Thornhill 2007:149). In this research, a point of reliability was that research design ensured reviewing the firm's EV CSR project management, using participant perspectives against the background of academic secondary research pertaining to EVs, project management and CSR projects. Only one of the researchers conducted all interviews, helping moderate different interviewer bias thus providing a second point of consistency in data gathering and reliability. The third point of reliability was the depth of understanding gained from EV CSR project management by targeting key role players in two similar CSR projects. With regard to research validity, Saunders et al. (2007:150) state that 'validity is concerned with findings - with the sole purpose of establishing whether the findings are really about what they appear to be about'. The findings needed to establish how the bank's EV CSR projects were managed and therefore needed the views of CSR managers who controlled bank funding, thus shareholder funding. The findings also needed the views of EVs who were leaders in their CSR projects and deemed managers in project success. Finally, the views of the school principals were needed who hoped for value for their high school and community from the project (Babbie \& Mouton 2004:122). From this triangulation, a distillation of perspectives and characteristics of CSR could be drawn (Flick 2009:444).

\section{Ethical consideration}

Ethics approval for the MComm study was received from the Faculty of Management ethics committee University of Johannesburg. Additionally, the retail bank issued V.C.P. with a letter giving permission to conduct the study as long as anonymity of the bank was retained. The bank approval trail is listed in V.C.P. Mcomm appendices as Appendix 1.

\section{Results \\ Team characteristics}

Table 2 draws attention to the difference in team size and managerial skills. Project 2 was at a disadvantage immediately having no management training. Yet, CSR managers, supposedly skilled at understanding project management, released funds to this project. Literature suggests that both teams need the firm to have established CSR support processes but Project 2 in particular needed skilled help, which it did not get and which the statements that follow indicate was not part of the current EV CSR project management support from the bank.

\section{Theme 1: Pre-implementation engagement}

Question 1 asked: 'At what stage did employees become involved in their CSR project?' seeking to understand how project needs had been established. All senior CSR managers gave similar responses, indicating that employees were expected to identify their own projects and plan their delivery to the community. A CSR manager response is recorded here as an example.

Senior CSR manager 1, project 1, male, said:

'For employee volunteering employees identify their own projects. Employees are not spoon-fed, they are left to think for themselves about how they will raise funds and get the project delivered from scoping, to planning and execution.'

The same question was then put to the bank employees involved in the projects. Sample responses are presented.

Project 1's employee 3, female, said:

'I got involved right at the beginning; we had a strategic planning session where we the employees agreed that we were going to do a CSR project.'

Project 2 employee perspectives appeared similar to those expressed in Project 1 in that team members indicated they felt they had been actively involved in their project.

Project 2's employee 2, male, noted:

'If you ask me I was involved right from the conception of the project.'

So there was seemingly little difference between the two project teams as to their initial actions to initiate a CSR project and their commitment from inception of each project.

The same question was then put to Project 1's school principal, female, who said:

'We had two different meetings before the whole project started to be delivered. We sat down together [with the EVs] and told them what we needed. So I was involved from the start. As every [project] phase was completed we verified quality to ensure that we were happy before the next stage.'

However, the response from Project 2's school principal, female, was:

'I was involved in terms of being informed that we have been selected as one of the schools that they would assist and then they gave us details of what they planned to do.'

Several points of disengagement and engagement are apparent. From the senior managers' perspective, their own degree of involvement with employees was knowingly limited ('not spoon-fed', 'think for themselves') although they were the appointed CSR management experts. These senior managers in interviews showed little inclination to be involved on a regular basis with either project's employees. The CSR managers at no point met the community members. Akpan (2008:500) argues that firms do indeed not always 
involve all stakeholders at the strategic planning stage - in this study, the CSR heads were neither at Project 1 or 2 employee internal CSR meetings nor at EV community meetings; they also did not want report back from these meetings. It is concerning that the CSR managers did not realise their own role in the creation of value from both projects. Poolthong and Mandhachitara (2009) suggest that some banks judge their CSR success only by how much available CSR funding was spent. This seems borne out by this bank's senior CSR managers' approving funding but not requiring other detail as to how the employees managed the planning and implementation of each project. This managerial attitude suggested EV CSR as being not as important as other aspects of the business as noted by Raman et al. (2012).

Employee involvement was another important activity from an optimised planning perspective. Firstly, both teams noted that they, as team members, had been committed to their team and their project from the project inception meeting. Project 1 then interfaced with the community to find out what needs their project should address. Conversely, Project 2 skipped this engagement link, deciding for the community what deliverables would be useful. The school principal in Project 2 was well aware that she had not been consulted and this might have been a risk if the school had not been so grateful for any sort of intervention. Conflict between Project 2 employees and their school could conceivably have arisen during project execution because no co-creation of outcomes had been undertaken. This finding agrees with that of Bhattacharya, Korschun, and Sen (2006) who state that it is vital for all relevant stakeholders to be part of CSR initiatives from inception for project maximised value creation.

Project 1 set project objectives after communicating with the school, whereas Project 2 did not. Literature notes advantages to communication and information flow between stakeholders in many aspects of a project. After an engagement process, all stakeholders should feel satisfied and accountable for project outcomes (Crain \& Abrahams 2008; Vachani \& Post 2012). Bank CSR managers who allocate funding assume that employee teams have the skills to manage a project, creating substantial risk when there is an under-skilled EV team. Raman et al. (2012) point out that CSR should be considered a strategic 'must have' by the entire leadership of a corporation to really add value. The bank acknowledges the importance of CSR corroborated by the fact that there are senior managers with the title of CSR manager who have the mandate to dispense financial budgets for EV CSR. There is also an active bank campaign to encourage employees to volunteer for CSR projects - yet, the findings suggest that there is a discontinuity in what the CSR managers believe is their role in support of these employees and indeed the bank. This supports the view held by Campbell (2007) and Raman et al. (2012) that this South African bank like much other organisations researched may see CSR EV projects as a 'nice to have' by senior leadership rather than a 'must have'. The bank did have a clearly stated policy on risk management in CSR implementation when working with NPOs and government, with many risk mitigation opportunities. Yet, CSR managers offered only a financial management oversight with EV projects - projects which could be considered high risk, not only in terms of not applying funds properly but also in unknowingly creating friction between the community and the bank (brand identity risk).

An interesting final finding in Theme 1 was the perspective of the team members individually. They drew the researchers' attention to the fact that each team had what could be referred to as a 'we commit' stage at their first initiation of project meetings. This is an important concept that should be considered in how a CSR EV team forms internal support links before performing.

\section{Theme 2: Project execution}

Question 2 reviewed how well the existing bank CSR process for releasing resources for a community initiative served the projects. The research instructed participants to: 'Examine the existing CSR funding process (a flowchart provided by the CSR managers) and comment on the process'. The senior CSR managers all noted problems by employees in fulfilling the funding access criteria. An example being the response of senior CSR manager 3, project 2, male:

'While the flowchart is correct [from the bank's perspective] problems arise because the due diligence section of process is vigorous but it is intended to protect the community and our staff. We ask for documents that are often not in place for most communities. This is frustrating for both the employee volunteers and the communities as the documents then take time to get and our experience shows that there are often delays in releasing funding.'

The same question was then put to the bank employees for both projects.

Project 1's employee 1, male, said:

'The flowchart is accurate of what the bank wants but what takes so much time is the administrative part from the school before gaining financial support from the CSR managers. You submit all your proposed project financial needs to the CSR managers at the project beginning but they will only pay out later in the year. The application for this project was put in early February, the fund was only paid out in September. Everything that we did at the school had to come out of fundraising until then - we could not wait for the procedural go-ahead from the CSR team as per process flow otherwise we were not going to achieve our own time-line objective on the project. We took a team decision that we could make it work with or without the CSR team.'

Project 2's employee 2, male, noted:

'It takes a very long time to get through the CSR admin process. Some community places like our school do not necessarily have all the documents that are required by CSR to get funding but we can't get the funding without them. The CSR has no plan of what to do if the community actually can't get those documents for really valid reasons.'

The teams established project timelines, but the required CSR internal process held up both projects. The teams felt 
compelled to honour their agreed timelines with the community. They felt a sense of frustration at the process, which corroborated the findings by Bhattacharya et al. (2006) that the employee does indeed feel accountable for project delivery. The teams built the bank's brand with the community on their own determination to deliver; yet, the CSR managers showed little cognisance of this projectcommunity dedication. Terblanche (2014:4) notes that 'interactions between people everywhere in the firm is the new locus of value creation'. This view suggests that, without a bank's framework for EV CSR being more than just a process for financial compliance, the complete value of such initiatives may remain largely untapped. The senior CSR managers indicated that they were well aware of the procedural hurdles, yet the inflexible process was applied. Varajão et al. (2014) draw attention to the value of resolving conflict that exists over how bank funding is released, because not serving their internal customer - the employeeactually results in harming the bank's external customer relationship and perhaps future bank viability (Pearce \& Robinson 2011).

Finally, the projects' implementation from the community perspective is worth considering. Project 1's school principal, female, said:

'Renovation of the classes was a bit challenging, as we had to move children around; with the good collaboration with the project team - we handled it well.'

Project 2's school principal, female, noted:

'The team worked extremely hard and there were days that they finished at midnight. The team leader even came in with her father, mother and siblings, and they were all scrubbing the floors very late.'

Both teams built the reputation of the bank with the community through their dedication even with the challenges faced.

\section{Theme 3: Value creation}

The third question requested stakeholders to define how the CSR projects added value to the bank. The research used the Porter's value chain diagram (Porter 2001:52) to give all participants a similar definition for what the question was trying to establish.

When you look at this diagram of a value chain and think of Porter's nine functions in the diagram representing bank activities, suggest how you think these EV CSR projects have added value.

Here the findings show that the bank's CSR managers did understand the type of value EV projects could generate across the organisation, yet they failed to manage in a manner that supports optimised value creation. Several responses from participants are presented to show the understanding of participants of the diversity of value that could be created.
Senior CSR manager 1, project 1, male, was quite clear on the value of EV CSR from a marketing perspective:

'The bank has the opportunity for publicity when it does CSR. We $[E V S]$ can tell a lot of life-changing stories about communities that have benefited from CSR programmes making our firm known. This means publicity without paying, even though it is not the primary CSR intention. In the course of adding value to the communities, we also get them to use our bank products, which means more business for the bank. We [the EVs] get a good reputation for our organization.'

Senior CSR manager 2, project 2, male, suggested other valued outcomes:

'The most impact is felt in sales and marketing. But CSR also forces the organisation to comply with a government CSR scorecard, so reporting on community projects from an overall bank reporting and compliance perspective which is important. Better understanding of the communities and better appreciation of the challenges that the community goes through, this also speaks to bank product design.'

Senior CSR manager 3, project 2, male, added:

'Value creation touches on a few things like HR. For example, if you have two organisations to choose from - one that cares for its employees, communities and so on and one that cares less, you will definitely choose the more caring one to work for or bank with. If you contribute to the sustainability of the community, you are contributing to the sustainability of your own business. We also expose our brands in the communities.'

Project team members demonstrated similar understanding of value creation and a value chain.

Project 1's employee 3, female, stated:

'Looking at the value chain - if I go into an organisation as an employee I will like to know what they do for CSR. Value creation comes into the CSR value chain perfectly with the service since we are delivering service to the community.'

Project 1's employee 2, male, said:

'Looking at the value chain, I think our project creates patches of value everywhere. In my view we have added value mostly in the operations space of the bank because we operationally worked with the community as bank employees showing our bank's willingness to help.'

The responses from Project 2 participants were as supportive of the value of CSR efforts for the community and the bank as those of Project 1 employees.

Project 2's employee 3, male, said:

'CSR is the backbone of an organisation; it cuts across all these processes.'

Project 2's employee 2, male, said:

'I think CSR initiatives by an organisation give value everywhere.'

The school principals were not shown the value chain, but were asked what they considered of value from the projects. 
Project 1's principal, female, noted:

'The team are planting back into the community. The bank is helping the community lift the standard for those that are disadvantaged. It feels good that they have done something for the community.'

Project 2's school principal, female, said:

'They started teaching our learners the value of saving. We approached their local bank branch to give us a talk from which we opened accounts for a good number of our learners. I also opened a new account. We all view the bank as someone who cares about us and therefore as a part of us.'

Senior managers and employees from both projects indicated that value creation from a CSR activity appeared in many places in a value chain. Yet, under Themes 1 and 2, CSR managers indicated how little they did to support an EV project other than deliver financial resources if all paperwork criteria had been fulfilled. Senior managers were clearly aware from their responses of how a CSR project could impact on the bank's future performance. Pandi-Perumal et al. (2015:14) note that limited support for some projects may arise from an institutional lack of understanding of how certain project types (in this case EV projects) contribute in terms of value, but in this bank it seems the CSR managers were well versed in understanding the potential for added value across the organisation from EV CSR activities.

\section{Findings and implications}

Firstly, financial aspects of CSR compliance by CSR management in this research overrode all other needs of the project teams. Although the triple outcome of ESG might be important to the bank, it was not effected in the EV projects. Both teams struggled with the current process set for EV activities by bank policy. Project 2's EV members missed several key project management criteria for success. They also ended up doing a great deal of hard physical work on their own because they did not grasp the concept of co-creating value and, therefore, proactively sharing responsibilities with the community that could have been established at the first meetings of the school and EVs. Project 1's EVs were better at project management but had to embark on comprehensive fundraising in order to cover a financing gap before bank CSR funding was released. These aspects added pressure to both teams who work as bank employees and also do volunteer work. It is recommended that the bank devise an inclusive CSR process to consider factors from an employee or a community perspective. The development of a process would need research and would likely be bank specific.

Secondly, it was of significance that the communities, while acknowledging the hard work of the employees, gave the bank credit in terms of acknowledging improved brand awareness and a tendency to have a future financial relationship (opening accounts). Jane (2008) notes the need for both CSR beneficiary and CSR investor clearly setting out mutually attainable and predefined returns on investment.
Considering the link the recipients immediately noticed between receiving upgraded facilities and their improved awareness of the bank suggests that pursuit of RI is to be considered seriously. Further research will be required as to how to extract maximised value (success factors) with minimised risk for both parties in an RI relationship.

Thirdly, the importance of the role that employees play in penetrating a community and building the bank's relationship with that community cannot be overstated. Training for project management skills, particularly that of communicating, to overcome project challenges is essential. If the value of employee relationships with community stakeholders can be quantified by further research, it would help the case for CSR managers valuing employee contributions to the bank.

Fourthly, streamlining the number of bank required documents and reducing the internal lead time for approving CSR initiatives seem necessary. Employees have limited time that they can apply to CSR EV projects, and the findings demonstrate that employees can become bogged down by the bank's current process.

\section{Conclusion}

Limitations of this study are that retail banks compete for market share, so the case of this bank's EV project management might not be relevant in another bank; a second limitation is that researchers were not privy to understanding the type of training the CSR managers had on managing EV projects, so the extent to which the bank requires CSR managers to support these projects was not empirically ascertained. How do employees and the community engage for CSR initiatives? The process is seemingly unclear (apart from the finance application). Project recipients were grateful for the value delivered to them through the bank's CSR intervention although it appeared in this study that only because of great tenacity on the part of the employees that the projects were delivered. And, can this engagement be improved? The research findings clearly support much of the existing secondary research in that project management principles need to be applied if EV projects are to maximise return for investments made. The literature presented also indicates that the bank's CSR managers reflect much of what secondary research indicates needs to change to promulgate effective ESG. We suggest that currently the bank's management of CSR efforts does not yet fully demonstrate a 'practical' understanding of the importance of supporting their employee CSR efforts with respect to value creation for the bank.

\section{Acknowledgements Competing interests}

The authors declare that they have no financial or personal relationships that may have inappropriately influenced them in writing this article. 


\section{Authors' contributions}

Both V.C.P. and P.H.T. were responsible for experimental design and conceptual contributions to this article. V.C.P. collected and analysed field data as part of a master's minor dissertation supervised by P.H.T.

\section{References}

Akpan, W., 2008, 'Corporate citizenship in the Nigerian petroleum industry: A beneficiary perspective', Development Southern Africa 25(5), 497-511. https:// doi.org/10.1080/03768350802447602

Babbie, E. \& Mouton, J., 2004, The practice of social research, South African edition, Oxford University Press, Cape Town.

Barkay, T., 2012, 'Employee volunteering: Soul, body and CSR', Social Responsibility Journal 8(1), 48-62. https://doi.org/10.1108/17471111211196566

Beasley, M.W. \& Frigo, M.L., 2010, 'ERM and its role in strategic planning and strategy execution', in J. Fraser \& B.J. Simkins (eds.), Enterprise risk management: Today's leading research and best practices for tomorrow's executives, pp. 31-50, Wiley,
lom Hoboken, NJ.

Bergeron, D.M., 2007, 'The potential paradox of organizational citizenship behavior: Good citizens at what cost?', Academy of Management Review 32(4), 1078-1095. Good citizens at what cost?', Academy of Manage
https://doi.org/10.5465/AMR.2007.26585791

Bester, V. \& Cronjé, F., 2014, 'The importance of a people-centred approach for Corporate Social Responsibility: A case study of Welverdiend and the surrounding community', TD: The Journal for Transdisciplinary Research in Southern Africa 10(1), 201-218.

Bhattacharya, C.B., Korschun, D. \& Sen, S., 2006, 'The role of corporate social responsibility in strengthening multiple stakeholder relationships: A field experiment', Journal of the Academy of Marketing Science 34(2), 158-166.

Bhattacharya, C.B., Korschun, D. \& Sen, S., 2009, 'Strengthening stakeholder Company relationships through mutually beneficial corporate social responsibility initiatives', Journal of Business Ethics 85, 257-272. https://doi.org/10.1007/ s10551-008-9730-3

Boznik, S. \& Mulej, M., 2010, 'Corporate social responsibility and requisite holism Supported by tradable permits', Systems Research and Behavioural Science 27(1), 23-35. https://doi.org/10.1002/sres.989

Bronn, P.S. \& Vidaver-Cohen, D., 2009, 'Corporate motives for social initiative: Legitimacy, sustainability, or the bottom line?', Journal of Business Ethics 87(1) 91-109. https://doi.org/10.1007/s10551-008-9795-z

Brusseau, J., Chiagouris, L. \& Brusseau, R.F., 2013, 'Corporate social responsibility: To yourself be true', Journal of Global Business and Technology 9(1), 53-63, viewed 03 September 2016, from http://search.proquest.com/docview/1444911551?acc ountid $=13425$

Campbell, J., 2007, 'Why would corporations behave in socially responsible ways? An institutional view of corporate social responsibility', Academy of Management Review 32(3), 946-967. https://doi.org/10.5465/AMR.2007.25275684

Corbin, J. \& Strauss, A., 1990, 'Grounded theory research: Procedures, canons and evaluative criteria', Qualitative Sociology 13(1), 3-21.

Crain, D.W. \& Abraham, S., 2008, 'Using value-chain analysis to discover customers strategic needs', Strategy \& Leadership 36(4), 29-39. https://doi.org/10.1108/ 10878570810888759

De Gilder, D., Schuyt, T.N.M. \& Breedijk, M., 2005a, Corporate volunteering and organizational outcomes: A theoretical model, viewed 03 September 2015, from http://cladea.org/proceedings_2013/wp-content/uploads/2014/02/2013XC-0107.pdf

De Gilder, D., Schuyt, T.N.M. \& Breedijk, M., 2005b, 'Effects of an employee volunteering program on the work force: The ABN-AMRO case', employee volunteering program on the work force: The ABN-AMRO case',
Journal of Business Ethics 61(2), 143-152. https://doi.org/10.1007/s10551-005Journal

De Paço, A. \& Nave, A.C., 2013, 'Corporate volunteering: A case study centred on the motivations, satisfaction and happiness of company employees', Employee Relations 35(5), 547-559. https://doi.org/10.1108/ER-12-2012-0089

Du Preez, R. \& Van Zyl, L.T., 2015, 'Toward the development of a corporate social responsibility leadership questionnaire: An adaptation of the LBI-2', SA Journal of Industrial Psychology 41(1), Art. \#1256, 1-18. https://doi.org/10.4102/sajip. v41i1.1256

Elo, S., Kääriäinen, M., Kanste, O., Pölkki, T., Utriainen, K. \& Kyngäs, H., 2014, 'Qualitative content analysis: A focus on trustworthiness', Sage Open 4(1), 1-10. https://doi.org/10.1177/2158244014522633

Elo, S. \& Kyngäs, H., 2008, 'The qualitative content analysis process', Journal of Advanced Nursing 62(1), 107-115. https://doi.org/10.1111/j.1365-2648.2007. 04569.x

Evans, W.R. \& Davis, W., 2014, 'Corporate citizenship and the employee: An organizational identification perspective', Human Performance 27(2), 129-146. https://doi.org/10.1080/08959285.2014.882926

Ferreira, P. \& De Oliveira, E.R., 2014, 'Does corporate social responsibility impact on employee engagement?', Journal of Workplace Learning 26(3/4), 232-247. https://doi.org/10.1108/JWL-09-2013-0070

Flick, U., 2009, An introduction to qualitative research, Sage, London.
Global corporate sustainability report, 2013, United Nations Global Compact Office, New York, viewed 03 September 2016, from http://www.unglobalcompact.org/ docs/about_the_gc/Global_Corporate_Sustainability_Report2013.pdf

Hamann, R., Van Duin, L., Appels, C., Taylor, E. \& Akor, E., 2006, 'Corporate citizenship in South African business education', South African Journal of Business Management 37(2), 45-53.

Hinson, R.E. \& Ndhlovu, T.P., 2011, 'Conceptualising corporate social responsibility (CSR) and corporate social investment (CSI): The South African context', Socia Responsibility Journal 7(3), 332-346. https://doi.org/10.1108/174711111111 54491

Institute of Directors Southern Africa, 2009, King code of governance for South Africa, Parktown: Institute of directors in Southern Africa, viewed 03 September 2015, from http://c.ymcdn.com/sites/www.iodsa.co.za/resource/collection/944450064F18-4335-B7FB-7F5A8B23FB3F/King_Code_of_Governance_for_SA_2009_ Updated_June_2012.pdf

Jane, A., 2008, SRI gains momentum, Euro Money Institutional Investor PLC, viewed 03 September 2015, from http://www.globalinvestormagazine.com/Article/ $2227213 /$ Search/Results/SRI-gains-momentum.html?Keywords= Jane ambachtsheer

KPMG, 2015, Building consumer trust is a core value for the consumer markets industry, viewed 11 January 2015, from http://www.kpmg.com/ZA/en/ IssuesAndInsights/ArticlesPublications/General-Industries-Publications/Pages/ Consumer-trust-rivals-growth.aspx

Louw, L. \& Venter, P., 2008, Strategic management: Winning in the Southern African marketplace, Oxford University Press Southern Africa, Cape Town.

Madden, K., Scaife, W. \& Crissman, K., 2006, 'How and why small to medium size enterprises (SMEs) engage with their communities: An Australian study', International Journal of Non-Profit and Voluntary Sector Marketing 11(1), 49-60. International Journal of Non-Profit
https://doi.org/10.1002/nvsm.4

Maignan, I. \& Ferrell, O.C., 2004, 'Corporate social responsibility and marketing: An integrative framework', Journal of the Academy of Marketing Science 32(1), 3-19. https://doi.org/10.1177/0092070303258971

Mandhachitara, R. \& Poolthong, Y., 2011, 'A model of customer loyalty and corporate social responsibility', Journal of Services Marketing 25(2), 122-133. https://doi. org/10.1108/08876041111119840

McCallum, S., Schmid, M.A. \& Price, L., 2013, 'CSR: A case for employee skills-based volunteering', Social Responsibility Journal 9(3), 479-495. https://doi.org/ 10.1108/SRJ-04-2012-0053

McPhee, W. \& Wheeler, D., 2006, 'Making the case for the added-value chain', Strategy \& Leadership 34(4), 39-46. https://doi.org/10.1108/10878570610 676873

Mostardeiro, M., 2007, 'CSR strategy formation processes: A multiple case study from Brazil', Social Responsibility Journal 39(1), 59-67. https://doi.org/10.1108/1747 1117200700007

Ofori, D.F., Nyuur, R.B. \& S-Darko, M.D., 2014, 'Corporate social responsibility and financial performance: Fact or fiction? A look at Ghanaian banks', Acta Commerci financial performance: Fact or fiction? A look at Ghanaian ba
14(1), Art. \#180, 1-11. https://doi.org/10.4102/ac.v14i1.180

Oyetayo, O.F., Oluwaseun, T.I. \& Dunsin, A.T., 2014, 'Corporate social responsibility and organizational profitability: An empirical investigation of United Bank for Africa (UBA) Plc.', International Journal of Academic Research in Business and Social Sciences 4(8), 205-214. https://doi.org/10.6007/IJARBSS/v4-i8/1089

Pandi-Perumal, S.R., Akhter S., Zizi, F., Jean-Louis, G., Ramasubramanian, C., EdwardFreeman, R. \& Narasimhan, M., 2015, 'Project stakeholder management in the clinical research environment: How to do it right', Frontiers in Psychiatry 6(71), clinical research environment: How to do it right', 1 -18. https://doi.org/10.3389/fpsyt.2015.00071IOD

Patel, L. \& Mushonga, H., 2014, 'Corporate social responsibility and development: A study of stakeholder perspectives of listed South African companies', Africanus 44(2), 50-63.

Pearce, J.A. \& Robinson, R.B., 2011, Strategic management: Formulation, implementation and control, McGraw Hill, New York.

Pérez, A. \& Del Bosque, I.R., 2014, 'Customer CSR expectations in the banking industry', International Journal of Bank Marketing 32(3), 223-244. https://doi. org/10.1108/IJBM-09-2013-0095

Poolthong, Y. \& Mandhachitara, R., 2009, 'Customer expectations of CSR, perceived service quality and brand effect in Thai retail banking', International Journal of Bank Marketing 27(6), 408-427. https://doi.org/10.1108/02652320910988302

Porter, M.E., 2001, 'The value chain and competitive advantage', in D. Barnes (ed.), Understanding Business Processes, pp. 50-66, Routledge, London.

Raman, M., Lim, W. \& Nair, S., 2012, 'The impact of corporate social responsibility on consumer loyalty', Kajian Malaysia 30(2), 71-93, viewed 04 September 2016 on consumer loyalty', Kajian Malaysia 30(2), 71-93, viewed 04 September 2016,
from http://web.usm.my/km/30(2)2012/KM\%2030\%20(2)\%20ART\%204\%20 (71-93).pdf

Richardson, J.R. \& Cragg, W., 2010, 'Being virtuous and prosperous: SRI's conflicting goals', Journal of Business Ethics 92, 21-29. https://doi.org/10.1007/s10551-0100632-9

Saunders, M., Lewis, P. \& Thornhill, A., 2007, Research methods for business students, Pearson Education Limited, London.

Smith, P.J. \& Cronje, G.J., 2003, Management principles: A contemporary edition for Africa, Juta \& Company Ltd, Cape Town.

Taleb, N.N., Goldstein, D.G. \& Spitznagel, M.W., 2009, 'Six mistakes executives make in risk management', Harvard Business Review 87(10), 78-81.

Terblanche, N.S., 2014, 'Some theoretical perspectives of co-creation and coproduction of value by customers', Acta Commercii 14(2), Art. \#237, 1-8. https:// doi.org/10.4102/ac.v14i2.237 
Theofilou, A. \& Watson, T., 2014, 'Sceptical employees as CSR ambassadors in times of financial uncertainty', in R. Tench, W. Sun \& B. Jones (eds.), Communicating corporate social responsibility: Perspectives and practice: Critical studies on corporate responsibility, governance and sustainability, vol. 6, pp. 335-382 Emerald Publishing Limited, Bingley. https://doi.org/10.1108/S2043-9059(2014) 0000006029

Tustin, D., Lighthelm, A., Martins, J. \& Van Wyk, A., 2005, Marketing research in practise, UNISA Press, Pretoria.

UNIDO, 2002, Corporate social responsibility: Implications for small and medium enterprises in developing countries, viewed 03 September 2015, from http:// unido.org/fileadmin/import/userfiles/puffk/corporatesocialresponsibility.pdf

Vachani, S. \& Post, J.E., 2012, 'Creating socially responsible value chains: Role of companies and NGOs', in U. Elg, A. Hadjikhani, N. Pervez \& P.N. Ghauri (eds.), Business, society and politics: Multinationals in emerging markets, pp. 17-39, Emerald Group Publishing Ltd, Bingley.
Van Os, A., Van Berkel, F., De Gilder, D., Van Dyck, C. \& Groenewegen, P., 2015, 'Project risk as identity threat: Explaining the development and consequences of risk discourse in an infrastructure project', International Journal of Project Management 33(4), 877-888. https://doi.org/10.1016/j.ijproman.2014. 10.016

Varajão, J., Dominguez, C., Ribeiro, P. \& Paiva, A., 2014, 'Critical success aspects in project management: Similarities and differences between the construction and the software industry', Technical Gazette 21(3), 583-589.

Waddock, S., 2010, 'From individual to institution: On making the world different', Journal of Business Ethics 94, 9-12. https://doi.org/10.1007/s10551-0110786-0

White, A.L., 2012, Redefining value: The future of corporate sustainability ratings, Private sector opinion, Global Corporate Governance Forum 29, viewed 03 September 2015, from http://www.ifc.org/wps/wcm/connect/7d9c6f804d9bd08 baeb7bf48b49f4568/IFC_PSO_29.pdf?MOD=AJPERES 